\title{
PENGARUH PROFITABILITAS, LIKUIDITAS, UKURAN PERUSAHAAN DAN LEVERAGE TERHADAP PERINGKAT OBLIGASI
}

\author{
Marwia Darma \\ marwiadama09@gmail.com \\ Universitas Ahmad Dahlan \\ Tina Sulistiyani \\ Tina_uad@yahoo.com \\ Universitas Ahmad Dahlan
}

\begin{abstract}
ABSTRAK
This study aims to determine the effect of profitability, liquidity, company size and leverage of the financial sector bond ratings in Indonesia Stock Exchange. The data in this research is secondary data obtained from www.idx.co.id. The total sample of 36 manufacturing sectors the company's bond period in 2017, using purposive sampling method. The analysis technique used is the logistic regression analysis and data processing using Eviews 9. The analysis showed that the positive effect on the profitability of bond ratings. liquidity positively affects bond ratings. Firm size positively affects bond ratings. Leverage negatively affect bond ratings. Companies should pay more attention and be able to increase the value of the company's liquidity so that companies ranked category of investment-grade bonds because investors are more interested in investing in bonds in the company investmentgrade category.
\end{abstract}

Keywords: Bond rating, profitability, liquidity, company size and leverage.

\begin{tabular}{l}
\hline \multicolumn{3}{c}{ PENDAHULUAN } \\
Sumber pembiayaan merupakan \\
salah satu faktor terpenting dalam \\
menjalankan suatu usaha. Salah satu \\
bentuk pendanaan yang dapat dilakukan \\
oleh perusahaan adalah dengan \\
menerbitkan obligasi. Obligasi adalah \\
surat utang jangka panjang yang dapat \\
dipindah tangankan yang berisikan \\
perjanjian antara pihak yang menerbitkan \\
untuk membayar imbalan berupa bunga \\
pada periode tertentu dan melunasi pokok \\
utang pada waktu yang telah ditentukan \\
kepada pihak pembeli obligasi (Bursa Efek \\
Surabaya, 2001). Purwaningsih (2008) \\
menyatakan bahwa, investasi pada obligasi \\
banyak diminati oleh para investor karena \\
obligasi memiliki pendapatan yang bersifat
\end{tabular}

tetap yang diperoleh dari bunga yang akan diterima secara periodik dan pokok obligasi pada saat jatuh tempo. Bagi para emiten, obligasi merupakan sekuritas yang relative lebih aman dibandingkan dengan saham karena biaya emisinya lebih murah dibandingkan dengan saham (Husnan, 2000). Investasi pada obligasi memang lebih aman, namun obligasi tetap memiliki risiko yaitu risiko tingkat suku bunga dan risiko perusahaan tidak mampu membayar kupon obligasi atau pokok hutang obligasinya.Risiko obligasi tersebut dapat diminimalisir melalui peringkat obligasi.

Peringkat obligasi menyatakan skala risiko atau tingkat keamanan suatu obligasi yang diterbitkan serta memberikan pernyataan yang informatif dan memberikan sinyal tentang probabilitas kegagalan utang suatu 
perusahaan. Keamanan suatu obligasi ditunjukkan oleh kemampuan suatu perusahaan dalam membayar bunga dan melunasi pokok pinjaman sehingga pemodal mendapatkan informasi mengenai peringkat obligasi dengan menggunakan jasa agen pemeringkat obligasi tersebut (Fauziah, 2014). Pemeringkatan menjadi hal yang wajib bagi setiap obligasi yang diterbitkan dan ditawarkan pada penawaran umum (Tandelilin, 2010:250). Peringkat yang diberikan merupakan salah satu acuan dari investor ketika akan memutuskan untuk membeli suatu obligasi (Amalia, 2013). Tandelilin (2010:251) menyatakan bahwa, tingkat peringkat obligasi bervariasi dari satu lembaga pemeringkat ke lembaga pemeringkat lainnya. Di Indonesia terdapat 2 (dua) lembaga pemeringkat obligasi yaitu PT. PEFINDO (Pemeringkat Efek Indonesia) dan PT. Kasnic Credit Rating Indonesia.Agen pemeringkat ini menilai dan mengevaluasi sekuritas utang perusahaan yang diperdagangkan secara umum, baik dalam bentuk peringkat maupun perubahan peringkat obligasi yang selanjutnya diumumkan ke pasar modal.

Secara umum peringkat obligasi dikategorikan menjadi dua yaitu kategori investment-grade (AAA, AA, A dan BBB) adalah kategori bahwa perusahaan atau negara dianggap memiliki kemampuan yang cukup dalam melunasi utangnya dan kategori non investment-grade $(\mathrm{BB}, \mathrm{B}$, CCC dan D) yaitu kategori perusahaan dikatakan tidak layak untuk berinvestasi bagi parainvestor. Salah satu fenomena yang terjadi di Indonesia yaitu peringkat obligasi daribeberapa emiten mengalami gagal bayar (default) yang kebetulan memiliki peringkat investment-grade, sehingga menimbulkan suatu pertanyaan apakah peringkat obligasi yang dinilai oleh agen pemeringkat di Indonesia akurat.

Tujuan Penelitian dalam artikel ini Untuk mengetahui pengaruh variabel Profitabilitas berpengaruh terhadap peringkat obligasi serta untuk mengetahui pengaruh variabel Likuiditas berpengaruh terhadap peringkat obligasi, untuk mengetahui pengaruh variabel Ukuran Perusahaan berpengaruh terhadap peringkat obligasi dan untuk mengetahui pengaruh variabel Leverage perusahaan berpengaruh terhadap peringkat obligasi.

\section{REVIEW LITERATUR DAN HIPOTESIS}

\section{Profitabilitas}

Rasio profitabilitas adalah rasio yang digunakan untuk mengukur kemampuan perusahaan menghasilkan laba dan juga untuk mengetahui efektifitas perusahaan dalam mengelola sumbersumber yang dimilikinya. Apabila laba perusahaan tinggi maka akan memberikan peringkat yang naik pula sehingga variabel ini dikatakan dapat mempengaruhi prediksi peringkat obligasi.

Profitabilitas atau kemampuan memperoleh laba adalah suatu ukuran dalam presentase yang digunakan untuk menilai sejauh mana perusahaan mampu menghasilkan laba pada tingkat yang diterima. Angka profitabilitas dinyatakan antara lain dalam angka sebelum pajak atau sesudah pajak, laba investasi, pendapatan per saham, dan laba penjualan. Nilai profitabilitas menjadi norma ukuran bagi kesehatan perusahaan. Analisis profitabilitas bertujuan untuk mengukur kemampuan perusahaan dalam memperoleh laba baik dalam hubungannya dengan penjualan, asset, maupun modal sendiri.

Jadi hasil profitabilitas dapat dijadikan sebagai tolak ukur ataupun gambaran tentang efektivitas kinerja manajemen ditinjau dari keuntungan yang diperoleh dibandingkan dengan hasil penjualan dan investasi perusahaan.Profitabilitas dapat mengukur kemampuan perusahaan untuk memeperoleh laba baik dalam hubungannya dengan penjualan, total aktiva, maupun laba dari modal sendiri.Rasio ini mampu memberikan gambaran seberapa efektif suatu 
perusahaan sehingga dapat memberikan keuntungan bagi perusahaan. Semakim baik profitabilitas perusahaan maka semakin baik peringkat yang akan diberikan. Selaras dengan pendapat Bouzita \& Young dalam Afiani (2012), semakin tinggi tingkat profitabilitas perusahaan maka semakin rendah risiko ketidakmampuan membayar (default) dan semakin baik peringkat yang diberikan terhadap perusahaan tersebut. Dalam penelitian ini rasio yang digunakan untuk mengukur profitabilitas adalah ROA karena rasio ini mampu menilai kemampuan perusahaan untuk menggunaka rata-rata asetnya dalam menghasilkan laba. Rasio ini juga dapat mewujudkan hubungan investasi baru yang ditunjukkan pada modal kerja dikaitkan dengan total aset yang digunakan perusahaan.

\section{Likuiditas}

Sutrisno (2005:70) menyatakan bahwa, rasio likuiditas adalah kemampuan perusahaan dalam memenuhi kewajiban finansial jangka pendek tepat pada waktunya. Semakin tinggi tingkat likuiditas perusahaan maka akan semakin tinggi peringkat obligasi yang diberikan kepada perusahaan tersebut. Rasio likuiditas yang tinggi mengindikasikan obligasi pada perusahaan tersebut termasuk dalam kategori investmentgrade, karena dengan aset lancar yang lebih tinggi daripada hutang lancar menunjukkan kemampuan perusahaan dalam memenuhi kewajiban jangka pendek kepada investor tepat pada waktunya.

\section{Ukuran Perusahaan}

Brigham \& Houston (2006) mendefinisikan ukuran perusahaan sebagai rata-rata total penjualan bersih untuk tahun yang bersangkutan sampai beberapa tahun, ukuran perusahaan juga merupakan karakteristik suatu perusahaan dalam hubungannya dengan struktur perusahaan. Ukuran perusahaan membantu investor untuk mengetahui kemampuan perusahaan dalam membayar bunga obligasi secara periodic serta melunasi pokok pinjaman yang dapat meningkatkan peringkat obligasi perusahaan. Sawir (2004) menyatakan bahwa, Perusahaan yang berukuran besar mempunyai berbagai kelebihan dibanding perusahaan berukuran kecil. Kelebihan tersebut yang pertama, adalah ukuran perusahaan dapat menentukan tingkat kemudahan perusahaan memperoleh dana dari pasar modal. Kedua, ukuran perusahaan menentukan kekuatan tawar-menawar (bargaining power) dalam kontrak keuangan. ketiga, ada kemungkinan pengaruh skala dalam biaya dan return membuat perusahaan yang lebih besar dapat memperoleh lebih banyak laba. Miswanto dan Husnan (1999) menyebutkan bahwa, ukuran perusahaan dapat diukur dengan menggunakan total aset, penjualan atau ekuitas. Proksi yang digunakan untuk mengukur ukuran perusahaan dalam penelitian ini adalah dengan menggunakan total aset yang dimiliki oleh perusahaan.

\section{Leverage}

Leverage terjadi pada saat perusahaan menggunakan sumber dana yang memberikan beban tetap. Tujuan penggunaan leverage ialah untuk meningkatkan pengembalian kepada para pemegang saham biasa.

Kasmir (2009:158) menyatakan bahwa leverage merupakan rasio yang digunakan untuk mengetahui seberapa besar kemampuan perusahaan dalam membayarkan seluruh kewajibannya (baik kewajiban jangka pendek maupun jangka panjang). Jenis rasio hutang (leverage ratio) dalam penelitian ini adalah debt to equity ratio. Debt to equity ratio merupakan rasio yang digunakan untuk mengukur seberapa besar total modal sendiri yang dibiayai dengan total utang bagi kreditur. semakin besar rasio ini semakin merugikan karena berarti risiko yang ditanggung semakin tinggi. 
Sebaliknya bagi perusahaan semakin besar rasio ini semakin baik karena DER yang rendah menandakan pendanaan yang disediakan pemilik sebagai jaminan semakin tinggi dan batas pengamanan bagi peminjam semakin besar.

Maylia (2007) menyatakan bahwa, leverage menunjukkan proporsi dalam penggunaan utang untuk membiayai investasi terhadap modal yang dimiliki. Burton et al,. (1998) menyatakan bahwa, semakin rendah leverage perusahaan maka semakin tinggi peringkat obligasi yang diberikan oleh perusahaan. Nilai leverage yang tinggi menunjukan perusahaan tersebut masuk dalam kategori noninvesment grade karena tanggungan beban bunga utang sehingga risiko yang dihadapi semakin besar. Semakin rendah nilai leverage, maka semakin kecil aktiva yang didanai dengan utang, sehingga semakin baik peringkat yang diberikan terhadap perusahaan tersebut. Proksi rasio leverage yang digunakan dalam penelitian ini adalah debt to equity ratio (DER).

\section{Peringkat Obligasi}

Peringkat obligasi merupakan sebuah informasi yang menyatakan tentang keadaan perusahaan dan potensi tindakan apa yang akan dilakukan guna menghadapi hutang yang dimiliki perusahaan. Secara umum peringkat obligasi mencerminkan kemungkinan penunggakan perusahaan dalam melakukan pembayaran kewajiban (kupon dan nilai nominal) dari obligasi tersebut atau mengukur beberapa risiko kegagalan yang akan terjadi, contohnya seperti peluang emiten atau peminjam mengalami kondisi tidak dapat membayar hutang yang dimiliki sehingga hal ini akan menimbulkan kerugian yang tidak diharapkan oleh investor yang biasa di interpretasikan melalui ketidaksanggupan emiten dalam membayar bunga obligasi dan nilai nominal pada akhir jatuh tempo (Weston dan Brigham, 1994:298).

\section{Hipotesis}

H1 : Profitabilitas berpengaruh positif terhadap peringkat obligasi.

$\mathrm{H} 2$ : Likuiditas berpengaruh positif terhadap peringkat obligasi.

H3 : Ukuran Perusahaan berpengaruh positif terhadap peringkat obligasi.

$\mathrm{H} 4$ : Leverage berpengaruh negatif terhadap peringkat obligasi.

\section{METODE PENELITIAN}

\section{Populasi dan Sampel}

Penelitian ini berbentuk penelitian assosiatif dan menggunakan pendekatan kuantitatif yang bertujuan untuk mengetahui hubungan dua variabel atau lebih (Sugiyono, 2012:114). Penelitian ini dilakukan pada Sektor Manufaktur di Bursa Efek Indonesia perioda 2017. Penelitian ini dapat diakses melalu situs resminya www.idx.co.id. Di dalam situs tersebut menyediakan data-data yang diperlukan dalam penelitian ini.

Populasi merupakan wilayah generalisasi yang terdiri dari objek atau subjek yang memiliki kualitas atau karakteristik tertentu yang ditetapkan oleh peneliti untuk dipelajari dan kemudian ditarik kesimpulannya (Sugiyono, 2012:115). Populasi dalam penelitian ini adalah perusahaan sektor manufaktur yang tercatat di BEI. Sampel adalah sebagian dari populasi yang terdiri atas sejumlah anggota yang dipilih dari populasi (Sugiyono, 2012:116).

\section{Jenis Sumber Data}

Penelitian ini menggunakan jenis data kuantitatif. Data kuantitatif adalah data yang berbentuk angka (Sugiyono, 2012:13). Data kuantitatif yang digunakan dalam penelitian ini adalah Profitabilitas, Likuiditas, Ukuran Perusahaan, Leverage, dan Peringkat Obligasi. Sumber data yang digunakan dalam penelitian ini adalah sumber data sekunder. Data sekunder merupakan data yang bukan diusahakan sendiri pencatatanya dan pengumpulannya 
oleh peneliti namun di lakukan oleh pihak lain. Data sekunder dalam penelitian ini diperoleh dari situs resmi Bursa Efek Indonesia melalui www.idx.co.id.

\section{Teknik Pengumpulan Data}

Teknik pengumpulan data dalam penelitian ini adalah dokumentasi. Dokumen ini merupakan dokumen berupa laporan keuangan tahunan perusahaan Perusahaan sektor manufaktur yang terdapat di BEI.

\section{Definisi Operasional}

Variabel penelitian menurut Sugiyono (2010) adalah sesuatu hal yang berbentuk apa saja yang ditetapkan oleh peneliti untuk dipelajari sehingga diperoleh informasi tentang hal tersebut, kemudian ditarik kesimpulannya.

\section{Variabel Terikat}

Variabel terikat pada penelitian ini yaitu peringkat obligasi untuk perusahaan yang mendapatkan peringkat obligasi berkategori investment-grade (idAAA, idAA, idA, idBBB) diberi kode 1 sedangkan untuk perusahaan yang mendapatkan peringkat obligasi berkategori non-investment grade (idBB, idB, idCCC, idD, dan yang tidak memiliki peringkat) diberi kode 0 .

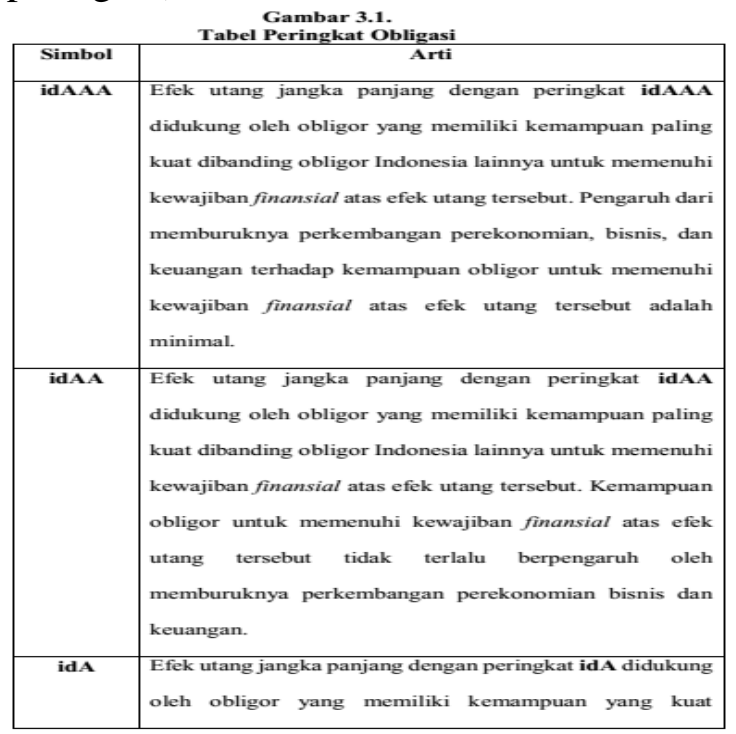

\begin{tabular}{|c|c|}
\hline & $\begin{array}{l}\text { dibanding obligor Indonesia lainnya untuk memenuhi } \\
\text { kewajiban finansial atas efek utang tersebut. Kemampuan } \\
\text { obligor untuk memenuhi kewajiban finansial atas efek } \\
\text { utang tersebut cukup terpengaruh oleh memburuknya } \\
\text { perkembangan perekonomian, bisnis dan keuaangan. }\end{array}$ \\
\hline idBBB & $\begin{array}{l}\text { Efek utang jangka panjang dengan peringkat idBBB } \\
\text { didukung oleh obligor yang memiliki kemampuan yang } \\
\text { memadai dibanding obligor Indonesia lainnya untuk } \\
\text { memenuhi kewajiban finansial efek utang tersebut. } \\
\text { Kemampuan obligor untuk memenuhi kewajiban finansial } \\
\text { atas efek utang tersebut lebih terpengaruh oleh } \\
\text { memburuknya perkembangan perekonomian, bisnis dan } \\
\text { keuangan dibanding obligor dengan peringkat lebih tinggi. }\end{array}$ \\
\hline IdBB & $\begin{array}{l}\text { Efek utang jangka panjang dengan peringkat idBB } \\
\text { didukung oleh obligor yang memiliki kemampuan yang } \\
\text { agak lemah dibanding obligor Indonesia lainnya untuk } \\
\text { memenuhi kewajiban finansial efek utang tersebut. } \\
\text { Kemampuan obligor untuk memenuhi kewajiban finansial } \\
\text { atas efek utang tersebut lebih terpengaruh oleh } \\
\text { memburuknya perkembangan perekonomian, bisnis dan } \\
\text { keuangan. }\end{array}$ \\
\hline IdB & $\begin{array}{l}\text { Efek utang jangka panjang dengan peringkat idBdidukung } \\
\text { oleh obligor yang memiliki kemampuan yang lemah }\end{array}$ \\
\hline & $\begin{array}{l}\text { dibanding obligor Indonesia lainnya untuk memenuhi } \\
\text { kewajiban finansial efek utang tersebut. Pemburukan } \\
\text { kondisi perekonomian, bisnis dan keuangan dapat } \\
\text { berakibat pada ketidakmampuan obligor untuk memeuhi } \\
\text { kewajiban finansial atas efek utang tersebut. }\end{array}$ \\
\hline idCCC & $\begin{array}{l}\text { Efek utang jangka panjang dengan peringkat idCCC } \\
\text { menandakan terdapat risiko besar bahwa obligor tidak } \\
\text { mampu memenuhi kewajiban finansial atas efek utang } \\
\text { tersebut serta sangat bergantung pada perbaikan kondisi } \\
\text { perekonomian, bisnis serta keuagan. }\end{array}$ \\
\hline idD & $\begin{array}{l}\text { Efek utang jangka panjang dengan peringkat idD } \\
\text { menandakan obligor gagal memenuhi kewajiban finansial } \\
\text { atas efek utang pada saat jatuh tempo tersebut. Peringkat } \\
\text { idD ini akan diberikan tanpa menunggu sampai masa } \\
\text { tegang berakhir, kecuali PT PEFINDO yakin obligor akan } \\
\text { mampu memenuhi kewajibannya dalam masa tegang yang } \\
\text { ditetapkan. Peringkat idD juga dapat diberikan kepada } \\
\text { obligor yang sudah mengajukan pailit atau berhenti } \\
\text { berusaha. }\end{array}$ \\
\hline
\end{tabular}




\section{Variabel Independen}

Variabel bebas dalam penelitian ini adalah sebagai berikut :

\section{Profitabilitas}

Menurut Arthur (2008:88), indikator yang dapat digunakan sebagai pengukuran profitabilitas perusahaan adalah ROA (Return On Asset) yang merupakan pengembalian atas aset yang digunakan untuk menghasilkan pendapatan bersih perusahaan. Menurut Keown (2008:89) ROA dapat dihitung dengan rumus berikut:

2. Likuiditas

$$
\text { Return On Asset(ROA) : Laba bersih }
$$

$$
\text { Menurut Darsono }
$$

menyatakan rasio likuiditas adalah rasio yang bertujuan untuk mengetahui kemampuan perusahaan dalam membayar kewajiban jangka pendek. Dalam penelitian ini likuiditas menggunakan Current Ratio dengan rumus :

$$
\text { Current Ratio(CR): } \frac{\text { aktiva lancar }}{\text { utang lancar }} X 100 \%
$$

\section{Ukuran Perusahaan}

Ukuran perusahaan adalah skala besar kecilnya perusahaan ditentukan oleh total aset. Besar kecilnya perusahaan merupakan salah satu faktor yang dapat dipertimbangkan investor dalam melakukan investasi. Perusahaan yang memiliki ukuran besar akan lebih mudah memasuki pasar modal sehingga dengan kesempatan ini perusahaan membayar dividen besar kepada pemegang saham. Sementara perusahaan yang baru dan masih kecil akan mengalami banyak kesulitan untuk memiliki akses ke pasar modal sehinnga kemampuannya untuk mendapatkan modal dan memperoleh pinjaman dari pasar modal juga terbatas. Oleh karena itu maka mereka cenderung untuk menahan labanya guna membiayai operasinya, dan ini berarti dividen yang akan diterima oleh pemegang saham akan semakin kecil (Handayani dan Hadinugroho, 2009:66).
Ukuran Perusahaan $($ size $)=$ Log (total aset)

\section{Leverage}

$$
\text { Leverage menunjukkan }
$$
kemampuan perusahaan untuk memenuhi kewajiban baik untuk jangka pendek maupun jangka panjang. Analisis terhadap rasio ini diperlukan untuk mengukur kemampuan perusahaan dalam membayar utang (jangka pendek dan jangka panjang) apabila pada suatu saat perusahaan dilikuidasi atau dibubarkan (Sigit,2008). Leverage diproxikan dengan DER merupakan perbandingan antara total utang dibagi dengan modal DER dalam penelitian ini dirumuskan sebagai berikut :

$$
D E R: \frac{\text { total hutang }}{\text { total modal }}
$$

\section{Uji Instrumen}

a. Statistik Deskriptif

Statistik Deskriptif adalah statistik yang digunakan untuk menganalisa data dengan cara mendeskripsikan atau menggambarkan data yang telah terkumpul sebagaimana adanya tanpa membuat kesimpulan yang berlaku untuk umum atau generalisasi (Sugiyono, 2009).

b. Uji Normalitas

Uji normalitas bertujuan untuk membuktikan bahwa data yang dipergunakan berdistribusi normal. Model regresi yang baik adalah distribusi data normal atau mendekati normal (Thoifah, 2015). Uji normalitas menggunakan uji Jarque-Bera dengan menggunakan bantuan progam statistik. Dasar pengambilan keputusan jika probibalitas lebih besar atau sama dengan nilai alpha yang ditentukan, yaitu 5\%, maka data dikatakan berdistribusi normal, dan sebaliknya jika probibalitas kurang 5\% maka data berdistribusi tidak normal.

\section{Teknik Analisis Data}

Teknik analisis data yang digunakan dalam penelitian ini adalah 
Analisis Regresi Logistik. Menurut Ghozali (2006:261), dalam regresi logistik tidak memerlukan asumsi normalitas data pada variabel bebasnya. Pada umumnya, regresi logit digunakan apabila asumsi multivariate normal distribution tidak terpenuhi. Analisis dalam penelitian ini menggunakan program software Eviews versi 9.

Dalam penelitian ini tidak memerlukan uji normalitas data, karena pada regresi logistik tidak memerlukan asumsi normalitas pada variabel bebasnya. Artinya variabel penjelasnya tidak harus memiliki distribusi normal linier maupun memiliki varian yang sama dalam setiap kelompok (Kuncoro, 2001:217). Sebelum model regresi digunakan dalam memprediksi beberapa peneliti menganggap bahwa perlu menguji kelayakan model yang dibuat. Dalam pengujian hipotesis digunakan model regresi logit. Analisis tersebut dilakukan agar dapat menentukan masing-masing variabel bebas terhadap variabel terikat yaitu peringkat obligasi perusahaan tahun 2015-2017, karena variabel terikatnya merupakan variabel dummy yaitu variabel yang memiliki dua jenis alternatif.

\section{Analisis Deskriptif}

$\begin{array}{cccc}\text { statistik } & \text { yang digunakan untuk } \\ \text { menganalisa } & \text { data dengan cara }\end{array}$ mendeskripsikan atau menggambarkan data yang telah terkumpul sebagaimana adanya tanpa bermaksud membuat kesimpulan yang berlaku untuk umum atau generalisasi. Analisis statistik deskriptif mempunyai tujuan kegunaan untuk mengetahui gambaran umum dari semua variabel yang digunakan dalam penelitian ini, dengan melihat tabel statistik deskriptif yang menunjukkan hasil pengukuran mean, nilai minimal dan maksimal serta standar deviasi semua variabel tersebut. Mean dapat digunakan untuk mengestimasi berapa besar rata-rata populasi yang diperkirakan dari sampel yang akan digunakan. Standar deviasi bertujuan untuk melakukan penilaian terhadap dispersi rata-rata dari sampel yang digunakan. Nilai minimal dan maksimal berguna untuk melihat nilai minimal dan maksimum dari populasi dalam penelitian.

Statistik deskriptif memberikan gembaran atau deskripsi suatu data yang dilihat dari nilai rata-rata (mean), standar deviasi, varian, maksimum, minimum, sum, range, kurtosis dan skewness (Ghozali, 2016:19).

\section{Uji Regresi Logistik}

Pengujian dalam penelitian ini menggunakan regresi logistik (logistic regression). Regresi logistik digunakan dalam penelitian ini karena variabel bebasnya kombinasi antara metrik dan non metrik (Ghozali : 2002). Dalam teknik analisis ini tidak dilakukan uji normalitas, karena menurut Ghozali (2002) logistic regression tidak memerlukan asumsi normalitas pada variabel bebasnya. Asumsi multivariate normal distribution tidak dapat dipenuhi karena variabel bebasnya merupakan gabungan antara metrik dan non metrik. Persamaan regresi logistic dapat ditulis sebagai berikut (Gujarati, 2003: 605)

$$
\begin{aligned}
& \operatorname{Ln} \frac{p}{1-p}=\alpha+\beta_{1} X_{1}+\hat{a}_{2} X_{2}+\beta_{3} X_{3}+\beta_{4} X_{4}+e \\
& \text { Keterangan : } \\
& \operatorname{Ln} \frac{p}{1-p} \quad=\text { Peringkat Obligasi } \\
& \operatorname{Ln} \frac{p}{1-p} \quad=1 \text {, jika peringkat obligasi termasuk investmen-grade } \\
& \operatorname{Ln} \frac{p}{1-p} \quad=0 \text {, jika peringkat obligasi termasuk non investmen-grade } \\
& \alpha \quad \text { : Konstanta } \\
& \beta_{1-5} \quad \text { : Koefisien regresi } \\
& X_{1} \quad \text { : Profitabilitas } \\
& \mathrm{X}_{2} \quad \text { : Likuiditas } \\
& \mathrm{X}_{3} \quad \text { : Ukuran Perusahaan } \\
& \mathrm{X}_{4} \quad \text { : Leverage } \\
& \text { e : Standard Error }
\end{aligned}
$$




\section{HASIL PENELITIAN DAN PEMBAHASAN}

\section{Hasil Penelitian}

Berdasarkan tabel 4.2 dapat dideskripsikan dari 36 Perusahaan Manufaktur sektor aneka industri periode 2017 mempunyai rata-rata tingkat Peringkat Obligasi 0,500000 dengan deviasi standar 0,507093. Profitabilitas mempunyai rata-rata sebesar 5,697222 dengan deviasi standar 7,674082. Likuiditas mempunyai rata-rata sebesar 211,6589 dengan deviasi standar 136,0274. Ukuran Perusahaan mempunyai rata-rata 6,713056 dengan deviasi standar 0,708567 . Leverage mempunyai rata-rata 0,990556 dengan deviasi standar 0,742498 .

\section{Analisis Logistic Regression}

Analisis logistic regression digunakan untuk memperoleh gambaran probabilitas pengaruh antara variabel independen terhadap dependen. Persamaan logistic regression dapat dilihat dari tabel hasil Eviews 9 di bawah ini:

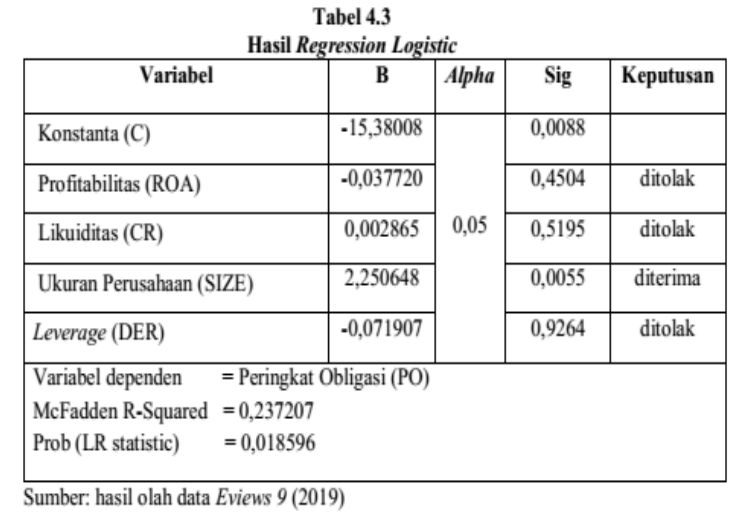

Tabel 4.3 menunjukkan bahwa nilai konstanta $\beta_{1}$ sebesar $-15,38008 \beta_{2}$ sebesar $-0,037720 \quad \beta_{3}$ sebesar 0,002865 $\beta_{4}$ sebesar 2,250648 $\beta_{5}$ sebesar 0,071907 . Nilai konstanta dan koefisien regresi $\left(\beta_{1}, \beta_{2}, \beta_{3}, \beta_{4}, \beta_{5}\right.$, ini dimasukkan ke dalam persamaan logistic regression berikut ini:

$$
L_{n}\left(\frac{P_{l}}{1-P_{i}}\right)=\beta_{1}+\hat{\mathrm{a}}_{2} R O A+\hat{\mathrm{a}}_{3} C R+\hat{\mathrm{a}}_{4} S I Z E+\hat{\mathrm{a}}_{5} D E R+u_{i}
$$

Berdasarkan persamaan tersebut, maka persamaan logistic regression sebagai berikut:

a. Konstanta

Nilai konstanta output dari Eviews 9 sebesar $-15,38008$ artinya jika tidak ada pengaruh variabel bebas yang terdiri dari profitabilitas, likuiditas, ukuran perusahaan dan leverage maka peringkat obligasi sebesar $-15,38008$.

b. Koefisien regresi Profitabilitas (ROA)

Nilai koefisien variabel profitabilitas diperoleh $-0,037720$ artinya jika profitabilitas naik 1 satuan maka peringkat obligasi turun sebesar 0,037720 dan jika profitabilitas turun 1 satuan maka peringkat obligasi naik sebesar 0,037720 .

c. Koefisien regresi Likuiditas (CR) Nilai koefisien regresi variabel likuiditas diperoleh 0,002865 artinya jika likuiditas naik 1 satuan maka peringkat obligasi naik sebesar 0,002865 dan jika likuiditas turun 1 satuan maka peringkat obligasi turun sebesar 0,002865 .

d. Koefisien regresi Ukuran Perusahaan (SIZE)

Nilai konstanta regresi variabel ukuran perusahaan diperoleh sebesar 2,250648, artinya jika size naik 1 satuan maka peringkat obligasi. naik sebesar 2,250648 dan jika size turun 1 satuan maka peringkat obligasi turun sebesar 2,250648.

\section{e. Koefisien regresi Leverage (DER)}

Nilai konstanta regresi variabel leverage diperoleh sebesar -0,071907 artinya jika leverage naik 1 maka peringkat obligasi turun sebesar 0,071907 dan jika leverage turun 1 satuan maka peringkat obligasi naik sebesar 0,071907. 


\section{Uji Hipotesis}

\section{Uji koefisien determinasi $\left(R^{2}\right)$}

Koefisien determinasi

digunakan untuk mengukur peruahaan manufaktur yang memiliki peringkat obligasi yang baik. menampilkan ukuran koefisien determinasi $\left(\mathrm{R}^{2}\right)$ dengan McFadden R-Squared juga berkisar antara 1 dan 0 (Gujarati, 2003: 605). Hasil uji koefisien determinasi $\left(\mathrm{R}^{2}\right)$ dalam penelitian ini adalah sebagai berikut:

\section{Tabel 4.4}

Hasil Uji Koefisien determinasi $\left(\mathrm{R}^{2}\right)$

\begin{tabular}{|c|c|}
\hline \multicolumn{2}{|c|}{ Summary } \\
\hline Mc Fadden $R$-Squared & 0,237207 \\
\hline
\end{tabular}

Sumber: hasil olah data Eviews 9 (2019)

Berdasarkan hasil uji koefisien determinasi $\left(\mathrm{R}^{2}\right)$ Tabel $4.4 \mathrm{di}$ atas, menunjukkan koefisien determinasi $\mathrm{R}$ squared yaitu sebesar 0,237207. Hasil ini menunjukkan bahwa $23,72 \%$ dari Peringkat Obligasi (Y) melalui internet di website Bursa Efek Indonesia periode 2017 dapat dijelaskan oleh profitabilitas, likuiditas, ukuran perusahaan, dan leverage, sedangkan sisanya 76,28\% berasal dari kondisi variabel terikat diterangkan oleh variabel bebas lain yang tidak diamati.

\section{Uji Simultan (Uji F)}

Uji $F$ digunakan untuk menunjukkan bahwa semua variabel independen yang dimasukkan ke dalam model mempunyai pengaruh secara serentak atau omnibus terhadap variabel dependen. Menguji statistik F dengan membandingkan nilai signifikansi dengan alpha jika nilai signifikansi < alpha maka Ha diterima. Gujarati (2003: 613). Berdasarkan hasil analisis data menggunakan Eviews 9, maka Uji Signifikansi Simultan (Uji F) dalam penelitian ini sabagai berikut:

Tabel 4.5

Hasil Uji Signifikansi Simultan (Uji F)

\begin{tabular}{|c|c|c|c|}
\hline Keterangan & Signifikansi & Alpha & Keputusan \\
\hline Prob (LR statistic) & 0,018596 & 0,05 & Diterima \\
\hline
\end{tabular}

Sumber: hasil olah data Eviews 9 (2019).

Hasil Regression Logistic tabel 4.5 menunjukkan signifikansi sebesar 0,018596 dan alpha sebesar 0,05 sehingga signifikansi $0,018596<0,05$ alpha. Hasil Uji $\mathrm{F}$ di atas menerima Hipotesis artinya profitabilitas, likuiditas, ukuran perusahaan dan leverage berpengaruh terhadap peringkat obligasi.

\section{Uji Individual (Uji T)}

Uji statistik $t$ digunakan untuk menunjukkan pengaruh variabel independen (profitabilitas, likuiditas, ukuran perusahaan dan leverage) secara parsial terhadap variabel dependen (peringkat obligasi). Hasil Regression Logistic tabel 4.6 menunjukkan uji t, maka dapat disimpulkan sebagai berikut:

Tabel 4.6

Hasil Uji Statistik t

\begin{tabular}{|c|c|c|c|}
\hline Variabel & Signifikansi & Alpha & Keputusan \\
\hline Konstanta (C) & $-15,38008$ & \multirow{5}{*}{0,05} & 0,0088 \\
\hline $\begin{array}{l}\text { Profitabilitas } \\
\text { (ROA) }\end{array}$ & $-0,037720$ & & 0,4504 \\
\hline Likuiditas (CR) & 0,002865 & & 0,5195 \\
\hline $\begin{array}{l}\text { Ukuran } \\
\text { Perusahaan } \\
\text { (SIZE) }\end{array}$ & 2,250648 & & 0,0055 \\
\hline Leverage (DER) & $-0,071907$ & & 0,9264 \\
\hline
\end{tabular}

Berdasarkan hasil uji statistik $t$ Tabel 4.6 hasil uji statistik t menunjukkan hasil sebagai berikut:

1) Profitabilitas (ROA)

Berdasarkan tabel 4.3 profitabilitas diperoleh nilai Sig sebesar 0,4504. Nilai tersebut lebih besar dari nilai alpha sebesar $0,05 \quad(\alpha)$. Artinya hipotesis tidak terdukung, artinya variabel profitabilitas (ROA) tidak berpengaruh terhadap 
peringkat obligasi.

\section{2) Likuiditas (CR)}

Berdasarkan tabel 4.3 likuiditas diperoleh Sig sebesar 0,5195. Nilai tersebut lebih besar dari alpha sebesar 0,05 $(\alpha)$. Artinya hipotesis tidak terdukung, artinya variabel likuiditas (CR) tidak berpengaruh terhadap peringkat obligasi.

\section{3) Ukuran Perusahaan (SIZE)}

Berdasarkan tabel 4.3 ukuran perusahaan diperoleh Sig sebesar 0,0055. Nilai tersebut lebih kecil dari alpha 0,05 $(\alpha)$. Artinya hipotesis terdukung, artinya variable ukuran perusahaan (SIZE) berpengaruh positif terhadap peringkat obligasi.

4) Leverage (DER)

Berdasarkan tabel 4.3 leverage diperoleh Sig sebesar 0,9264. Nilai tersebut lebih besar dari alpha sebesar 0,05 $(\alpha)$. Artinya hipotesis tidak terdukung, artinya variabel leverage (DER) tidak berpengaruh terhadap peringkat obligasi.

\section{Pembahasan}

\section{Hipotesis Pertama}

Berdasarkan hasil pengujian regresi logistik Ha1 tidak terdukung, sehingga tidak terdapat pengaruh profitabilitas terhadap peringkat obligasi. Hasil ini memberikan arti yaitu berapapun nilai profitabilitas entah kecil atau besar tidak akan memberikan pengaruh pada rating obligasi yang telah diterbitkan oleh perusahaan pemeringkat. Walaupun variabel profitabilitas tidak berpengaruh terhadap prediksi peringkat obligasi tetapi tanda dari koefisiennya telah sesuai dengan hipotesis yang diajukan, yaitu positif. Hasil penelitian ini tidak sesuai dengan penelitian yang dilakukan oleh Wirandika (2015) menyatakan bahwa profitabilitas berpengaruh negatif terhadap peringkat obligasi.

\section{Hipotesis Kedua}

Berdasarkan pengujian regresi logistik Ha2 tidak terdukung, sehingga tidak terdapat pengaruh likuiidtas terhadap peringkat obligasi. Rasio likuiditas menunjukkan kemampuan perusahaan untuk membayar kewajiban jangka pendek tepat pada waktunya. Semakin tinggi rasio likuiditas perusahaan maka semakin baik peringkat obligasi yang diberikan. Hasil penelitian ini menunjukkan bahwa nilai likuiditas yang negatif mengindikasikan bahwa perusahaan memiliki likuiditas yang tinggi kemungkinan besar tidak berada dalam kondisi yang efisien misalnya perusahaan tidak menggunakan pembiayaan melalui obligasi karena perusahaan memiliki dana internal yang besar dan cenderung memilih menggunakan dana internal terlebih dahulu dibandingkan sumber pembiayaan eksternal seperti penerbitan obligasisehingga mengakibatkan nilai perusahaan menjadi turun dan berpengaruh terhadap peringkat obligasi. Hasil penelitian ini sesuai dengan penelitian yang dilakukan oleh Manurung (2009) serta Dali, Sautma dan Mariana (2015) yang menunjukkan hasilbahwa likuiditas berpengaruh negatif signifikan terhadap peringkat obligasi.

\section{Hipotesis Ketiga}

Berdasarkan pengujian regresi logistik Ha3 terdukung, sehingga terdapat pengaruh ukuran perusahaan terhadap peringkat obligasi. Hasil tersebut menunjukkan bahwa perusahaan pemeringkat cenderung memperhatikan ukuran perusahaan sebagai variabel yang dapat mempengaruhi besar kecilnya peringkat obligasi pada perusahaan di Bursa Efek Indonesia. Hasil penelitian menunjukkan bahwa semakin besar ukuran perusahaan, maka semakin tinggi peringkat obligasi yang diberikan, hal ini disebabkan oleh tingginya tingkat kepercayaan investor terhadap perusahaan dengan ukuran yang besar. Perusahaan besar memiliki posisi yang kuat pada 
masing-masing industri yang digeluti sehingga mendukung peringkat obligasi yang diberikan.

Ukuran perusahaan juga dinyatakan sebagai determinan dari kesuksesan perusahaan, karena ukuran perusahaan dapat menentukan tingkat kemudahan perusahaan dalam memperoleh dana dari pasar modal dan kemungkinan pengaruh skala dalam biaya dan return mengakibatkan perusahaan yang lebih besar memperoleh laba yang lebih besar pula. Pada umumnya perusahaanperusahaan besar mempunyai risiko default yang lebih kecil daripada perusahaan-perusahaan menengah ke bawah. Hasil penelitian ini sesuai dengan penelitian yang dilakukan oleh Melani dan Paulus (2013) dan Sejati (2010) yang menunjukkan hasil bahwa ukuran perusahaan berpengaruh positif signifikan terhadap peringkat obligasi.

\section{Hipotesis Keempat}

Berdasarkan pengujian regresi logistic Ha4 tidak terdukung, sehingga tidak terdapat pengaruh leverage terhadap peringkat obligasi. Leverage menunjukkan proporsi penggunaan utang dalam membiayai investasi yang diproksikan dengan Debt to Equity Ratio (DER), apabila proporsi hutang yang dimiliki perusahaan lebih tinggi dari ekuitas maka perusahaan cenderung mempunyai kemampuan yang rendah dalam memenuhi kewajibannya. Leverage yang tinggi dalam sebuah perusahaan menunjukkan bahwa tingginya default risk keuangan perusahaan. Tidak semua perusahaan dengan tingkat leverage yang tinggi akan mengalami gagal bayar karena apabila perusahaan tersebut mampu mengelola dana yang dipinjamnya dengan baik dan benar maka perusahaan tersebut dapat menghasilkan profit, misalnya perusahaan menggunakan hutang tersebut untuk menambah produk baru atau membuka pabrik baru sehingga dengan penggunaan hutang tersebut mampu menghasilkan profit yang kemungkinan lebih besar dari pinjaman tersebut.

Terjadi perubahan arah pengaruh leverage dari negatif menjadi positif disebabkan karena terjadinya prinsip pertukaran antara risiko dengan manfaat dari penggunaan utang tersebut. Pada satu sisi, peningkatan utang yang tinggi dapat meningkatkan potensi kerugian atau kebangkrutan yang tidak dapat dihindari olehperusahaan (Hanafi, 2004). Pada sisi lain, penigkatan utang juga membawa manfaat yaitu penambahan modal untuk mengembangkan perusahaan tersebut. Hasil penelitian ini sesuai dengan penelitian yang dilakukan oleh Melani dan Paulus (2013), Estiyanti (2012) dan Hengki dan Eka (2015) yang menunjukkan hasil bahwa leverage berpengaruh positif tidak signifikan terhadap peringkat obligasi.

\section{KESIMPULAN DAN SARAN}

\section{Kesimpulan}

Berdasarkan hasil penelitian diatas, maka dapat disimpulkan sebagai berikut:

1. Profitabilitas (ROA) tidak berpengaruh positif terhadap peringkat obligasi oleh PT. PEFINDO pada sektor manufaktur di Bursa Efek Indonesia periode 2017.

2. Likuiditas (CR) tidak berpengaruh positif terhadap peringkat obligasi oleh PT. PEFINDO pada sektor manufaktur di Bursa Efek Indonesia periode 2017.

3. Ukuran Perusahaan (SIZE) berpengaruh positif terhadap peringkat obligasi oleh PT. PEFINDO pada sektor manufaktur di Bursa Efek Indonesia periode 2017.

4. Leverage (DER) tidak berpengaruh positif terhadap peringkat obligasi oleh PT. PEFINDO pada sektor manufaktur di Bursa Efek Indonesia periode 2017 


\section{Saran}

Untuk penelitian berikutnya agar pengambilan sampel dalam satu populasi sehingga tidak banyak data yang dihapus dan disarankan agar menggunakan faktor lain untuk mengetahui variabel lainnya yang dapat mempengaruhi peringkat obligasi yang tidak dijelaskan dalam penelitian ini. Peneliti selanjutnya juga disarankan agar menambah rentang waktu atau periode penelitian sehingga hasil yang diperoleh akan lebih akurat.

\section{DAFTAR PUSTAKA}

Almilia, L. S. dan V. Devi. 2007. FaktorFaktor Yang Mempengaruhi Prediksi Peringkat Obligasi Pada Perusahaan Manufaktur Yang Terdaftar Di Bursa Efek Jakarta. Proceeding Seminar Nasional Manajemen SMART Bandung:1-2.

Amalia, Ninik. 2013. Pemeringkatan Obligasi PT. Pefindo Berdasarkan Informasi Keuangan. Accounting Analysis Journal, 2 (2), h:140-147.

Brigham, Eugene, Joel F. Houston. 2006. Dasar-Dasar Manajemen Keuangan (Edisi10). Penerjemah Ali Akbar Yulianto. Jakarta: Salemba Empat.

Brister, B. M., R.E, Kennedy and P.Liu. 1994. The Regulation Efect ofBond Ratingon Yield. Journal of Finance, pp:539-572.

Bursa Efek Surabaya. 2001. Mengenal Obligasi. Over The Counter Fix Income Service.

Burton, B., Adam, M., and Hardwick, P. Liu. 1998. The Determinants of Credit Ratings in the United Kingdom Insuranse Industry. Journal of Business Finance and Accounting, 30 (3), pp:539-572.
Dali, Chandra Ly., Sautama Ronni dan Mariana Ing Malelak. 2015. Pengaruh Mekanisme Corporate Governance dan Rasio Keuangan terhadap Peringkat Obligasi. FINESTA, 3 (1), h:30-35.

Elton, Edwin, $\mathbf{J}$ and Martin J. Gruber. 1995. Modern Portfolio Theory and Investment Analysis. Fifth Edition. New York: John Wiley \& Sons, Inc.

Estiyanti, N. M. dan Gerianta M. Yasa.2012. Pengaruh Faktor Keuangan Dan Non Keuangan Pada Peringkat Obligasi Di Bursa Efek Indonesia. Jurnal Bisnisdan Ekonomi Universitas Udayana, 8 (1), h:227-249.

Hanafi, M . 2004. Manajemen Keuangan. Yogyakarta: BPFE

Hengki, Junius Sihombing dan Eka Nuraini Rachmawati. 2015. FaktorFaktor yang mempengaruhi Peringkat Obligasi pada Perusahaan yang Terdaftar di BursaEfek Indonesia. Jurnal Ekonomi, Manajemen dan Akuntansi, 24 (1), $\mathrm{h}: 95-116$.

Husnan, Suad. 2000. Manajemen Keuangan Teori dan Penerapan (Keputusan Jangka Panjang).Edisi 4. Yogyakarta: BPFE.

Kamstra, Mark., Peter Kennedy, and TeckKin Suan. 2001. Combining Bond Rating Forecasts Using Logit. Journal The Financial, 36 (2), pp:75-96.

Kilapong, Greacee Janly Victoria dan Lulu Setiawati. 2012. The Effect Of Accounting And Non Accounting Information To The Rating Of Company's Bond. Journal Accounting Department, pp:1-7. 
Kuncoro, Mudrajat. 2001. Metode Kuantitatif : Teori dan Aplikasi untuk Bisnis dan Ekonomi. Yogyakarta : UPP-AMP YKPN.

Luciana. 2007. Faktor-Faktor yang Mempengaruhi Prediksi Peringkat Obligasi pada Perusahaan Manufaktur yang Terdaftar di Bursa Efek Jakarta. Working Paper, download www.google.com.

Magreta dan Poppy Nurmayanti. 2009. Faktor-Faktor Yang Mempengaruhi Prediksi Peringkat Obligasi Ditinjau dari Faktor-Faktor Akuntansi dan Non Akuntansi.Jurnal Bisnis dan Akuntansi, 11 (3), h:143-154.

Manurung, A,. S. Desmon., dan T, Wilson.2009. Hubungan Rasio-Rasio Keuangan dengan Rating Obligasi”. Jurnal Finansial dan Bisnis. Februari 29, 2010.

Maylia, Pramono Sari. 2007. Kemampuan Rasio Keuangan Sebagai Alat Untuk Memprediksi Peringkat Obligasi (PT. PEFINDO). Jurnal Bisnis dan Ekonomi (JBE), 14 (2), h:172-182.

Melani, Kingkin Sandra dan Paulus Sulluk Kananlua.2013. Analisis Pengaruh Rasio Keuangan terhadap Peringkat Obligasi Perusahaan Manufaktur yang Terdaftar di Bursa Efek Indonesia Jurnal Ilmiah Manajemen, 8 (2), h:45-56.

Miswanto and Husnan, S. 1999. The Effect of Operating Leverage, Cyclicality and Firm Size on Bussines Risk.Journal of Business 1 (1), pp:162-175.

Ni Made Sri Kristina Sari, dan Ida Bagus Badjara. 2016. "Pengaruh Likuiditas, Ukuran Perusahaan, Leverage, dan Jaminan terhadap Peringkat Obligasi pada Sektor Keuangan. 5041-5069.
Purwaningsih, Anna. 2008. Pemilihan Rasio Keuangan Terbaik untuk Memprediksi Peringkat Obligasi : Studi pada Perusahaan Manufaktur Yang terdaftar di BEI. Jurnal Kinerja, 12 (1), h:85-99.

Raharja dan Sari.2008. Perbandingan Alat Analisis (Diskriminan dan Regresi Logistik) terhadap Peringkat Obligasi (PT. PEFINDO).Jurnal Maksi, , 8 (1),h:87-104.

Sari, W. P., T. Taufik. 2011. Faktor-Faktor Yang Mempengaruhi Prediksi Peringkat Obligasi Pada Perusahaan Manufaktur Yang Terdaftar Di Bursa Efek Indonesia. Jurnal Ekonomi, 3 (6), h:22-43.

Sugiyono. 2012. Metode Penelitian Bisnis. Bandung: Alfabeta.

Susilowati, Luky, dan Sumartono. 2010. Memprediksi Tingkat Obligasi Perusahaan Manufaktur yang Listing di BEI. Jurnal Mitra Ekonomi dan Manajemen Bisnis, 1 (2), h:63-17.

Sutrisno. 2005. Manajemen Keuangan Teori, Konsep dan Aplikasi. Yogyakarta: Ekonisi.

Teti Widyastuti. 2014. "Faktor-Faktor yang berpengaruh terhadapa peringkat obligasi pada perusahaan manufaktur yang terdaftar di BEI. h:152-186

Wahidahwati. 2002. Pengaruh Kepemilikan Manajerial dan Institusional pada Kebijakan Hutang Perusahaan : Sebuah Perspektif Theory Agency. Jurnal Riset Akuntansi Indonesia, 5 (1), h:1-16. 
Wiagustini, N. P. 2010. Dasar-Dasar Manajemen Keuangan. Denpasar: Udayana University Press.

Yuliana, R., Budiatmo, A., Prabowo, M.A., Arifin, T. 2011. "Analisis Faktor-Faktor yang Mempengaruhi Prediksi Peringkat Obligasi Pada Perusahaan Keuangan Yang Terdaftar Di Bursa Efek Indonesia”. Jurnal SNA XIV Aceh,(2), h:45-67. 